\title{
Made in China 2025: China's Strategy for Becoming a Global High- Tech Superpower and its Implications for the U.S. Economy, National Security, and Free Trade
}

Derek Adam Levine PhD

City University of New York, dlevine13@yahoo.com

Follow this and additional works at: https://digitalcommons.usf.edu/jss

pp. 1-16

\section{Recommended Citation}

Levine, Derek Adam PhD. "Made in China 2025: China's Strategy for Becoming a Global High-Tech Superpower and its Implications for the U.S. Economy, National Security, and Free Trade." Journal of Strategic Security 13, no. 3 (2020) : 1-16.

DOI: https://doi.org/10.5038/1944-0472.13.3.1833

Available at: https://digitalcommons.usf.edu/jss/vol13/iss3/1

This Article is brought to you for free and open access by the Open Access Journals at Digital Commons @ University of South Florida. It has been accepted for inclusion in Journal of Strategic Security by an authorized editor of Digital Commons @ University of South Florida. For more information, please contact digitalcommons@usf.edu. 


\title{
Made in China 2025: China's Strategy for Becoming a Global High-Tech Superpower and its Implications for the U.S. Economy, National Security, and Free Trade
}

\author{
Abstract \\ This article addresses how China's discriminatory trade practices and illicit means of \\ foreign technology acquisition under its Made in China 2025 plan undermine current \\ international trade orders and pose the greatest threat to its existence. Using both primary \\ and secondary data, this article highlights major implications that Made in China 2025 has \\ on free trade, the overall health of the U.S. economy, and U.S. national security. It proposes \\ a multilateral strategy to preserve the current trade system to steer China on track toward \\ honoring its commitment to free trade and identifies how the United States can maintain \\ supremacy throughout the twenty-first century.
}

\section{Acknowledgements}

I want to personally thank the reviewers and the editors who took time to read my article. My research is infinitely better because of their useful comments and suggestions. 


\section{Introduction}

China's General Secretary Xijing Ping's handling of the COVID-19 pandemic precipitated the recent wave of anti-Chinese sentiments pervasive throughout the United States, which resulted in more than 190,000 deaths in the United States and brought the global economy to a standstill, with nearly 30 million people unemployed. ${ }^{1}$ The pandemic spawned great debates among politicians and researchers regarding whether China's accession to the World Trade Organization (WTO) in 2001 has severely harmed the multilateral rule, which derives from the free trading system. Despite the Communist Party's discriminatory trade policies in the form of subsidies, antidumping measures, and discrimination against imports, China boasts about its outstanding record of compliance with the WTO's dispute settlement rules. The dispute settlement body takes years to render a decision, during which China benefits from its disputed policy while under review. Once the body makes a decision and if the challenge succeeds, China could comply, having reaped the benefits and remaining one-step ahead. ${ }^{2}$ If China appeals the decision, it again stays one-step ahead of the organization's response time when acting on violations. With the United States running a trade deficit of $\$ 378.6$ billion (2018) with China, the Trump Administration has vowed to hold China accountable for unfair trade practices that have severely damaged the American economy and businesses. 3

This article addresses how China's discriminatory trade practices and illicit means of acquiring foreign technology under its Made in China 2025 plan undermine current international trade orders and pose the greatest threat to its existence. This article also addresses how China's unfair trade practices have major implications for the overall health of the U.S. economy and U.S. national security. Revising WTO to meet challenges of the twenty-first century can resolve the challenges that China poses to the system of free and fair trade. This article reviews literature related to strategic trade policy consistent with developing and nurturing key industries. It then examines Xi Jinping's Made in China plan, designed to catch up to, surpass, and displace the United States as the leading world industrial power. This article addresses major implications that China's discriminatory trade practices have had on the United States, including how the community of member nations can preserve current international liberal trade order and get China on track to ensure that all WTO members 
follow the same rules. If this remains unaddressed, the world might be heading toward mercantilist policies that prioritize protectionism over free trade.

\section{Literature Review}

Consensus among researchers suggests that the state plays an important role in promoting technology, a role debated broadly by two schools of thought - the developmental state and Dirigiste. The developmental state approach examines developing the state's capacity and ability to create, guide, protect, and nurture key industries deemed important to greater economic development and growth until they have developed sufficiently to compete with and possibly surpass foreign rivals. The Dirigiste approach examines how industrialized nations assist and guide faltering or less competitive industries deemed important to a country's economy and national security. Enforcing economic direction and encouraging firms through various incentives such as subsidies and government procurement to follow a desired path accomplishes this. A third model, the China model blends characteristics of the developmental and Dirigiste schools.

\section{The Developmental Approach}

Chalmers Johnson introduced the state developmental approach in his book MITI and the Japanese Miracle, in which the author reviewed the origins of Japan's modern industrial policy and how it achieved great economic growth and success in a short time. 4 He attributed Japan's economic success to the ability of the country's Ministry of International Trade and Industry (MITI) to achieve state objectives by nurturing key strategic industries such as steel, chemical fertilizers, and shipbuilding. Many researchers have corroborated Johnson's perspective by applying his findings to other societies. Alice Amsden's Asia's Next Giant, for example, attributes South Korea's unprecedented economic growth over the past century to the government's economic interventions. 5 Amsden argues that all successful late-industrializing countries must have a strong centralized government that is capable of influencing the pace and direction of economic growth. The author argues that Korea's success rests heavily on a strong state and its ability to implement sound policies that promote development of indigenous industries. South Korea has grown faster than other economies because of the state's ability to exert power 
over private firms. ${ }^{6}$ Robert Wade's Governing the Market builds on Johnson's and Amsden's ideas by advancing the governed market theory, which emphasizes the government's role in promoting significant direct investment in key industries, with the intent of competing internationally. ${ }^{7}$

Although Johnson, Amsden, and Wade offer detailed empirical analyses of the economic success of East Asian countries that engaged in state economic interventions, Peter Evans took the state developmental approach a step further by considering which configurations and arrangements between state and industry are best suited to international competitiveness and economic success. ${ }^{8}$ Evans begins with the assumption that states play the role of agents of economic transformation best when characterized by what he labels "embedded autonomy" - when they best approximate the Weberian ideal type, which allots the state a degree of autonomy but enables it to maintain good working relationships with other sectors of society. When both characteristics are present, a state is developmental, and Evans argues that such a state plays a major role in a nation's economic development.

\section{The Dirigiste School}

Manufacturing Matters summarizes and articulates the Dirigiste position well, suggesting that the United States continues to send manufacturing overseas in the mistaken belief that the nation is better off if its economy moves toward greater service provision. ${ }^{9}$ United States economic decline is the result of the country's inability to find a niche in the market and thus attempts to remain competitive by exploiting cheap labor abroad. The United States can begin to become more competitive only if the government makes it possible for manufacturing facilities to remain in the country; it must help firms automate production. Increasingly relying on automation rather than unskilled human labor would reduce production costs and facilitate rapid diffusion of new technology to other economic sectors, making products more competitive.

Laura Tyson's book Who's Bashing Whom echoes this perspective, which argues that the poor state of the U.S. economy emanates from unfair and manipulative state interventionist policies with Japanese and European trading partners. ${ }^{10}$ To combat these disadvantages, Tyson proposes a cautious activism strategy, calling for the United States to open foreign markets to American products and suggesting that if unsuccessful, 
policymakers should threaten closure of U.S. markets and subsidize selective high-tech industries.

Adherents to the Dirigiste School differ, however, on appropriate policy responses. Gene Grossman disagrees with Tyson's argument that the United States should subsidize selective high-tech industries were the country's trading partners to engage in unfair trading practices. ${ }^{11}$ Although he acknowledges the advantages a nation gains were it to choose the correct industry to target, he also claims that policymakers do not have, and might never have, sufficient, reliable information to warrant the targeting of such industries. U.S. policy should instead create an environment conducive to innovation and entrepreneurship, one that prevents market failings. Government should promote education and industrial R\&D, which would improve international competitiveness.

\section{China Model}

Suisheng Zhao argues that China possesses attributes of both the developmental state and the Dirigiste School because the government blends essential features of a liberal market economy with authoritarian rule. The state has grown to respect private property and promote competition to a limited degree, while ensuring that the Communist Party maintains a firm grip over society. It does so by censoring media, silencing political opposition, selecting state-owned enterprises to become national champions through subsidies that force technology transfers from foreign companies in exchange for market share in select industries, and engaging in human rights violations. ${ }^{12}$ Since technological determinism represents a driving force behind cultural, societal, and political changes, Chinese leaders have created a smart city in which it maintains control over society using facial recognition cameras and social credit scores, allowing it to monitor dissidents or anyone who challenges the Communist Party. ${ }^{13}$ However, China diverges from Johnson's version of the developmental model regarding subsidies, given primarily to state-owned enterprises rather than private businesses, to guide, nurture, and protect industries that develop the country's economy and national security. 


\section{China’s Industrial Policy}

For over a decade, the Chinese government has made its intentions clear of becoming an excellent industrial power, beginning with introduction of its National Medium and Long Term Plan for Science and Technology (20062020) (MLP), the predecessor to Made in China 2025. The Chinese government stated in the plan that it would channel 2.5 percent of the nation's total GDP to research and development in areas of strategic importance to future economic development and national security. ${ }^{14}$ The government listed 16 pillar industries, including semiconductors, aviation, and telecommunications, all of which are important to China becoming a top-tier industrialized nation. ${ }^{15}$ Most importantly, MLP stated that China is to develop capabilities for indigenous innovation and move into leading positions in new science-based industries by the end of the plan period. ${ }^{16}$ Despite massive investment in key industrial sectors, China realized obvious technological gaps that exist in comparison to the West, and it thus committed to obtaining the world's most advanced technology illicitly in half the time it would have taken the country to produce it on its own, while avoiding the cost and with the United States the most frequent target. Hu Xitao mentions in Classified Insider regarding development and construction of China's aviation industry, a report written for policy leaders and political elites to follow to reduce the technological divide with the West. ${ }^{17}$

President Xi Jinping's Made in China 2025 plan uses elements of the state development approach and the Dirigiste School to place China on a path to restoring what it believes is its rightful position as the world's most prominent global power by 2050, the hundredth anniversary of the founding of the People's Republic of China. The plan lays out targeted goals, whereby China will no longer be a mere consumer of the world's most advanced technology, but active in creating, leading, and defining international technological standards. China's goal is to free itself from dependency on foreign technology and develop indigenous, high-tech capabilities that satisfy its lucrative domestic market and serve and strengthen its military. However, after nearly losing a generation of experts and scientists to Mao Zedong's social experiments-The Great Leap Forward and the Cultural Revolution-the technological gap with the West has widened and would take decades to catch up using a strong, government-led industrial policy. ${ }^{18}$ 
China has a severe shortage of engineers and scientists needed to develop an excellent industrialized economy. The primary cause of the country's lack of innovativeness stems from social experiments that Mao Zedong implemented, which led to mistreatment of scholars and experts because they were opponents of the revolution. He jailed, tortured, killed, or relocated to the countryside for reeducation hundreds of thousands of citizens, setting China's economic development back generations. ${ }^{19}$ Another prominent reason for its lack of innovativeness is that one-third of students who study abroad in advanced fields of science and engineering do not return to China once they graduate due to better opportunities found in countries such as the United States and United Kingdom. ${ }^{20}$ The brain drain has become a growing problem for China, especially since the Tiananmen Incident in 1989. The reason students do not return after graduation is because of social, economic, or political problems; in China, political alienation, low income, poor living conditions, insufficient research facilities, and mismanagement of highlevel manpower are the reasons intellectuals seek opportunities abroad. ${ }^{21}$

Realizing its limitations and its desire to develop excellent technology, China engages in discriminatory practices to catch up with and surpass the West in advanced industries. Such practices include protecting its markets, trading market share for technology transfers, issuing massive subsidies to state-owned enterprises and large private companies, and acquiring foreign technology illicitly, all of which are contrary to its commitments to being a WTO member. The plan prioritizes acquisition of advanced technology from foreign companies, with the intent of assimilating the technology locally, digesting it, and innovating ittweaking or advancing existing technology so it can become a global industry leader. ${ }^{22}$

\section{Illicit Acquisition of Foreign Technology}

\section{Cyber Espionage}

Engaging in commercial espionage is as simple as hacking into a computer, which is on the rise and costs a thousand of the largest U.S. companies more than $\$ 300$ billion annually, and China is the world's worst offender. ${ }^{23}$ Thieves steal approximately $\$ 500$ billion in trade secrets, 
research and development, and products that give companies a competitive advantage from U.S. companies each year. Such theft has also resulted in the loss of nearly 2 million U.S. jobs and technological superiority in industries related to national defense. ${ }^{24}$ China has organized and developed a well-coordinated campaign that targets Western governments and companies by covertly stealing military and industrial secrets using malicious spyware such as GhostNet in pursuit of shortcuts that bolster economic and military modernization. ${ }^{25}$ Espionage results in shorter timeframes while costing significantly less money. China would otherwise have spent 10 years and $\$ 10$ million on research and development if it did not steal secrets and bribe competitors and foreign nationals at the rate of about $\$ 1$ million each to achieve the same if not better results. ${ }^{26}$

Companies thus must contract or go out of business because they lose competitive advantages to theft of the latest generations of technology, or they suffer major losses by avoiding lucrative markets. A loss of advanced technology results in a loss of high- tech jobs, where wages are approximately 75 percent greater than the national average. ${ }^{27}$ Such theft also represents a major threat to security; when military and high-tech secrets are stolen, military superiority decreases. To engage in espionage, the Chinese government recruits a range of people, organizations, and operatives to obtain military and industrial technologies. Such threats come from not only intelligence operatives, but ordinary Chinese citizens whom the government bribed, coerced, or employed. Since no entity controls or coordinates the PRC's technology acquisition centrally, it is difficult to combat, and the United States has thus suffered severe losses to its economy, simultaneously posing a threat to national security. ${ }^{28}$

\section{Obtaining Classified Information}

China's two professional intelligence agencies-Ministry of State Security (MSS) and the PLA General Staff's Military Intelligence Department (MID)- have been effective at acquiring foreign technology illicitly, even though they account only for a small percentage of the PRC's foreign science and technology collection. Non-professionals, including PRC officials, bureaucrats, students, scientists, researchers, and other visitors to the West, conduct much of the data collection. ${ }^{29}$ MSS, MID, and other PRC-controlled organizations coerce such individuals into working on their behalf. The Chinese government knows that since money motivates 
these individuals, it can, with the right amount, bribe them to commit espionage. $3^{\circ}$ The Chinese government contacts PRC nationals and offers them large amounts of money to steal sensitive technology and ship it back to China.

Over 100,000 PRC nationals annually attend U.S. universities or remain in the United States after graduation. The Chinese government is interested in recruiting Chinese-born scholars who remain in the United States. and have established strong networks in their respective fields. They represent an asset because they might have access to important scientific technology and classified data once employed in the United States. For example, born in Taiwan, Wen Ho Lee acquired an education in the United States and went on to work for Los Alamos. The United States accused him of giving the PRC classified information on the W-88 warhead during the mid-1980s and information on nuclear weapons during the 1990s. Although the evidence to convict him was insufficient, he pled guilty to downloading classified information onto an unsecured computer and served time under house arrest. ${ }^{31}$

\section{Front Companies}

Overseas governments and state bureaucracies have set up front companies to get around laws that prevent sensitive technology transfers and acquisitions between companies from disparate nations. Establishing a company in a foreign country and hiding its identity so that the public believes it is a local company seeking profit rids suspicion of obtaining advanced technology and transferring it to the home country. According to the 1999 Cox report, more than 3,000 PRC corporations exist in the United States, many of which connect to the PLA or a state intelligence service operative. ${ }^{2}$ This is particularly troublesome for law enforcement to monitor because the Chinese government, and possibly intelligence services, has become savvy at blurring lines between commercial, profitseeking enterprises and enterprises established to commit espionage. 33

\section{Joint Ventures}

China has particularly been sending record numbers of scientists and engineers to Silicon Valley in pursuit of commercial secrets to establish business ventures with American companies where staff members might have access to secret technology.34 Stealing company secrets does not 
require advanced and sophisticated methods; foreign intelligence services have learned that using computer networks, people can easily access and steal U.S. government and private sector information that would normally require years of expensive technology or human assets to acquire. A person can download sensitive documents onto USB flash drives, small enough to conceal. The losses that a company can accrue from having its secrets stolen are enormous. 35

\section{Purchasing of American Companies}

Another tactic the Chinese government uses to get secret data and technology is purchasing American companies. In 1996, the Chinese purchased Sunbase Asia, an American company that produces ball bearings for the U.S. military. No information is available regarding whether anyone has transferred sensitive technology back to China. ${ }^{6}$ With the purchase of high-tech companies, China could easily gain technology that could strengthen its economy and military.

\section{Purchasing Technology}

PRC representatives who worked in high-tech Chinese companies or who were government officials often bought sensitive technology, including electronic equipment, due to the carelessness of the Department of Defense, whose interest at the time was disposing of excess property. Without properly checking codes, the department sold such equipment without assessing whether someone could use it for military purposes. If the codes had revealed that the equipment was a dual-use technology, the government would have prohibited its sale. Due to considerable carelessness, many PRC companies were able to bid on military equipment and technology, avoiding suspicion by using American names to alleviate fears that the technology would make its way to China. The PRC was able to purchase a multi-axis machine tool profiler used to build wingspans for the F-14 fighter for under $\$ 25,000$ when the original price was over $\$ 3$ million. 37

\section{Technology for Market Share}

To access the Chinese market, foreign companies are unofficially required to enter a joint venture with a Chinese firm under terms that require them to share advanced technology and technological expertise. Since China has 
1.4 billion people, with 350 million living in first-world conditions who are potential consumers of foreign products, foreign companies know how advantageous it is to access the Chinese market. China has lured foreign manufacturers into long-term, cooperative arrangements by guaranteeing a large portion of their market as long as the manufacturers are willing to educate local companies on how to produce such products and familiarize them with the equipment, technology, and management needed to do so. 38

\section{Implications for the United States}

The current liberal international order advocates free market principles, under which companies compete over the price and quality of a product with the expectation that players will comply with rules that uphold free and fair market competition. Increased competition always improves business because more products appear on the market, among which customers can choose. Greater competition forces companies to seek efficient ways of keeping production costs down by adopting the latest technologies and product features. Cheaper products that contain the most advanced technology have always been attractive to consumers.

As China continues to manipulate the liberal international order in its favor by using protectionism, unfair subsidization, and theft of sensitive technology, U.S. companies stand to lose substantial wealth and technological superiority in high-end economic sectors and the military. American companies have lost nearly $\$ 300$ billion in revenue, which has cost the country over 2 million jobs. 39 Without greater help from the American government to cover their losses or implement protectionist policies, they had no choice but to contract, resulting in less money invested in research and development. A slowing down of innovation and product efficiency is also likely, which will make products less competitive internationally and in turn affect the overall health of the economy because innovation generates spillover into the private sector and military. 40

As companies begin to contract, downsizing will include a reduction in the number of scientists and engineers who create, innovate, and thereby add value to the broader economy and military. Such contractions discourage students from entering engineering fields, hindering the country's ability to make substantial contributions to its economy in the future. Conversely, 
when businesses are doing well, they expand and increase their numbers of employees, and when they are doing poorly, they downsize, laying off workers, which affects state and local economies.

Technological superiority represents the foundation of the strength of the U.S. military. Soldiers are sent into combat knowing they have access to the world's most sophisticated and advanced weapons. ${ }^{41}$ However, maintaining a technological advantage comes only from maintaining a highly diverse, sophisticated economy that benefits financially when it upgrades its products. As companies continue to contract, downgrade, or go out of business due to theft of their intellectual property by the Chinese, the technological advantage regarding defense will slow while China's strengthens.

Contrary to evidence presented in this article, Chinese experts, and scholars disagree with what they call unsupported assumptions regarding China breaking WTO rules; they claim a stellar record of abiding by WTO regulations. When the settlement dispute renders decisions regarding the violations, China will make the necessary reforms. According to Ambassador Liu Xiaoming, the current administration uses much U.S. rhetoric of China's non-compliance with WTO regulations, and constant references to theft of technology as causes of the trade deficit, as a scapegoat for its domestic problems. This began with the 2008 financial crisis that led to a decrease in exports to China and a decline in overall manufacturing as a result of U.S. business closures. $4^{2}$ The 2008 subprime mortgage crisis led to a rise in asset prices. The income distribution gap in the United States has widened like never before, and manufacturing has declined. U.S. goods trade deficits hit a new high since 2009 and have been growing ever since, leading China to redirect its economic policy to greater independence and self-sufficiency through greater diversification of domestic markets. The United States' strict policy of prohibiting the sale of dual-use technologies (that is, military and civilian use) urged China to greater development and strengthening of its core high-tech sectors. 43

\section{Conclusion}

China's limitations regarding development of advanced technology led it to acquire such technology illicitly, which includes forced technology transfers, commercial espionage, intellectual property rights violations, 
and issuing of large subsidies to state-owned enterprises and private companies. China's opaqueness and its initial handling of COVID-19 encouraged the international community to reconsider the effectiveness of multinational institutions such as WTO. China's predatory policies pose the greatest threat to preservation of the international liberal order and the health and security of each member nation. WTO has thus far offered no effective remedy for dealing with the challenges China poses to the international system of trade. The organization has antiquated rules and has not updated them in nearly 25 years. It also does not have a formidable, pronounced way to redress the problem of China's lack of openness, the country's consistent data falsification, and the government's channeling of money to state-owned enterprises that operate covertly as private institutions. Thus, it is difficult for member nations to express grievances against the country's predatory practices, prompting calls for new rules to cope with China's violations of WTO regulations. 44

The Trump Administration's strategy for dealing with China was to place a 15 percent tariff on $\$ 300$ billion worth of imports, designed to protect American industries that continually suffer from China's discriminatory trade practices and intellectual property violations. 45 However, the strategy led to a trade war between the two countries, since China retaliated with tariffs ranging from 5 percent to 7 percent on more than $\$ 75$ billion worth of U.S. goods. 46 As part of phase one of an agreement with China, Trump is willing to reduce tariffs imposed on China substantially if it agrees to purchase $\$ 200$ billion of American goods by December 2021.47

History suggests that China has lied to each president from Clinton to Obama regarding promises to implement nondiscriminatory policies, respect intellectual property rights, and allow American banks to operate and compete fairly in China. 48 Without a timely remedy to deal with China's predatory practices, American companies will suffer immense losses and might even go out of business before WTO renders a decision if an entity files a grievance. For the preservation and legitimacy of the liberal international trade order, removing bureaucratic red tape that prevents the dispute settlement body from rendering decisions quickly and sternly would resolve this issue. 
To redress the China challenge, it would be advantageous for the American government to work with WTO members on revising the organization to include a system that both caps and monitors direct and indirect product subsidization. A rule should also disallow distinction between a private company and state-owned enterprise that receives government subsidies. A country should no longer be able to declare itself a developing nation to receive special treatment regarding subsidization and import taxes. $49 \mathrm{~A}$ definition should consider a country as developing only if it constitutes less than 0.5 percent or more of world trade. $5^{0}$ China has the second largest economy in the world and a rule should disallow it from selfreporting as a developing nation; all high-income countries should abide by the same rules.

WTO should also be responsible for monitoring member countries, especially those that have a long history of violating intellectual property laws, which include industrial policies that enhance the competitive position of domestic firms. Technology theft poses a problem to domestic companies' ability to compete in the market, and WTO should address and prevent it. WTO can address this easily were the Dispute Settlement Board to render a decision within 6 months of an entity filing a complaint, with the appeal process included. This would resolve all issues related to violations of intellectual property unfairly discriminating against foreign products or issuance of non-agreed on subsidies to indigenous companies and enterprises. A violating country should suffer sanctions immediately based on current and future financial gains it accumulated or expected to accumulate from discriminatory policies. The country must then either appeal or accept the decision.

It takes up to six years for the Dispute Settlement Board to reach a decision. ${ }^{11} \mathrm{~A}$ complainant must file an initial suit and request that a panel convene to hear the case. It then takes approximately 45 days for the WTO to appoint a panel and up to six months for it to conduct and conclude an investigation. In most cases, it takes up to a year for a WTO panel to complete its proceedings and issue a decision, after which the defendant can accept and comply with the decision or file an appeal with the appellate body, which takes up to 90 days to issue a decision..$^{2}$ The appellate body's decision is final, and countries must comply within the allotted time. Worsening the process, compensation covers losses that incurred only since the date that the complainant filed the grievance.53 If 
the defendant refuses to comply, the WTO can enforce countermeasures against the state. This system encourages countries like China to break the rules since it might have up to 6 years to benefit from them before repealing them. If a country violates the same rule three times, WTO members should consider suspending that nation from the organization.

If members cannot initiate such an agreement, the only alternative is for the industry to move toward state-sponsored markets, based on limited workings of the free market. For the United States to maintain its international supremacy and meet China's ascension of becoming a great power, it must continue to upgrade its diverse, sophisticated economy in which innovation spills over from the commercial side of the industry to the military, and vice versa. The COVID-19 pandemic suggests that it is important for the United States to diversify its supply chain, reducing dependency on China, stockpiling security essentials, and encouraging high-tech innovation. This includes automating manufacturing facilities so that the country can continue to maintain its status as the most advanced industrialized country.

\section{Endnotes}

${ }^{1}$ Anurag Mann, "U.S. COVID-19 deaths near 190,000; Iowa and South Dakota emerge as new hotspot," Reuters, September 9, 2020, https://www.reuters.com/article/ushealth-coronavirus-usa/u-s-covid-19-deaths-near-1900oo-iowa-and-south-dakotaemerge-as-new-hotspots-idUSKBN2601HS.

${ }^{2}$ Seung-Youn Oh, "Convenient Compliance: China's Industrial Policy Staying One Step Ahead of WTO Enforcement," Fellows Program on Peace, Governance, and Development in East Asia, EAI Working Paper, May 2015, https://www.files.ethz.ch/isn/191745/13.05.2015.pdf.

3 Office of the United States Trade Representative, "The Peoples Republic of China," accessed August 13, 2020, https://ustr.gov/countries-regions/china-mongoliataiwan/peoples-republic-

china\#: :text=The\%2oU.S.\%2ogoods\%20and\%2oservices,way)\%2ogoods\%2otrade\%2 oduring\%202018.

4 Chalmers Johnson, MITI and the Japanese Miracle: The Growth of Industrial Policy 1925-1975 (California: Stanford University Press: 1982), 84.

5 Alice Amsden, Asia's Next Giant (New York: Oxford University Press, 1989), 147.

6 Amsden, Asia's Next Giant, 14.

7 Robert Wade, Governing the Market: Economic Theory and the Role of Government in East Asian Industrialization (New Jersey: Princeton University Press, 1990), 10.

8 Peter Evans, Embedded Autonomy (New Jersey: Princeton University Press, 1995), 30.

${ }_{9}^{9}$ Stephen Cohen and John Zysman. Manufacturing Matters: The Myth of the PostIndustrial Economy. (New York: Basic Books, 1987) 92.

${ }^{10}$ Tyson, Laura D' Andrea, Who's Bashing Whom? Trade Conflict in High Technology Industries (Washington, DC: Institute for International Economics, 1992) 254. 
${ }^{11}$ Gene M. Grossman, "Strategic Export Promotion: A Critique," in Strategic Trade Policy and the New International Economics, ed. Paul R, Krugman (Massachusetts: The MIT Press, 1986), 48.

${ }^{12}$ Suisheng Zhao, "The China Model: Can It Replace the Western Model of Modernization?," Journal of Contemporary China 19, no. 65 (2010): 434-35, https://doi.org/10.1080/10670561003666061.

${ }^{13}$ Ming Xia (professor of Asian policy studies, CUNY Graduate Center), in discussion with the author, November 2019.

14 Chinese Government Web Portal, "Chinese Government's Official Web Portal," accessed September 27, 2010, http://www.gov.cn/english/2006-02/09 /content_183426.html.

15 Cong Cao, Richard P. Suttmeier, and Dennis Fred Simon, "China's 15-Year Science and Technology Plan,” Physics Today, accessed June 24, 2019, https://chinaus.uoregon.edu/pdf/final\%2oprint\%20version.pdf.

${ }^{16}$ Cao et al., "China's 15-Year Science."

${ }^{17}$ Xitao Hu. The Construction and Development of China Aviation Industry: Classified: Insider Information, (Zhongguo Hangkong Shiye De Jianshe Yu Fazhan: Neibu Ziliao), Book consists of collection of reports for Government Officials and Party Leaders, 1997, (Benshu Baokuo Le Gei Zhengfu Guanyuan He Zhengdang Lingdaoren Baogao De Heji, 1997), 295.

${ }^{18}$ Baichun Zhang (professor of History, Institute for the History of Natural Science at the Chinese Academy of Sciences), in discussion with the author, August 2010.

19 Chengzi Li professor of Aeronautics, School of Aeronautics and Astronautics, Beihang University), in discussion with the author, August 2010.

${ }^{20}$ Dun Zhang, "China Faces On-Going Brain Drain,” The Epoch Times, August 21, 2013, http://www.theepochtimes.com/n3/103521-china-faces-ongoing-brain-drain/.

${ }^{21}$ Zhang, "Brain Drain."

22 Ming Xia, discussion.

${ }^{23}$ Cristina Maza, "China Involved in 90 Percent Espionage and Industrial Trade Secrets Theft Department of Justice Reveals,” Newsweek, December 12, 2018, https://www.newsweek.com/china-involved-90-percent-economic-espionage-andindustrial-secrets-theft-1255908.

24 Joshua Phillip, "The Staggering Cost of Espionage Against the United States," The Epoch Times, October 22, 2013, https://www.theepochtimes.com/the-staggering-costof-economic-espionage-against-the-us_326002.html.

25 Joe Frusci (Professor of History, City University of New York) and John Oakley (Commander, Army National Guard), in joint discussion with the author, August 2019.

${ }^{26}$ Xitao Hu, The Construction and Development of China Aviation Industry: Classified: Insider Information, (Zhongguo Hangkong Shiye De Jianshe Yu Fazhan: Neibu Ziliao), Book consists of collection of reports for Government Officials and Party Leaders, 1997, (Benshu Baokuo Le Gei Zhengfu Guanyuan He Zhengdang Lingdaoren Baogao De Heji, 1997), 295.

${ }_{27}$ Robert E. Scott, “The China Trade Toll,” Economic Policy Institute, July 30, 2008, https://www.epi.org/publication/bp219/.

${ }_{28}$ James Mulveron (Vice-President, Defense Group International) in discussion with the author, July 2013.

29 Frusci and Oakley, discussion.

$3^{30}$ Sheo Nandan Pandey "China's Economic Espionage Prowess," ISPSW, www.ispsw.de.

${ }^{31}$ Larry Wu-Tai Qin, "Four Chinese Espionage Investigations," PBS, January 15, 2004, http://www.pbs.org/wgbh/pages/frontline/shows/spy/spies/four.html.

${ }^{2}$ Terrance John Cox, "U.S. National Security/Commercial Concerns with the People's Republic of China," United States House of Representatives, May 25, 1999 https://www.govinfo.gov/content/pkg/GPO-CRPT-105hrpt851/pdf/GPO-CRPT105hrpt851.pdf,13. 
33 Cox, "U.S. National Security," 13.

34 "Operations," Global security.org,

http://www.globalsecurity.org/intell/world/china/mss-ops.htm, (accessed January 15, 2011).

35 Frusci and Oakley, discussion.

36 "U.S. National Security/Commercial Concerns with the People's Republic of China," United States House of Representatives, May 25, 1999,

http://www.house.gov/coxreport/, 46.

37 Terrance John Cox, "U.S. National Security/Commercial Concerns with the People's Republic of China," United States House of Representatives, May 25, 1999 https://www.govinfo.gov/content/pkg/GPO-CRPT-105hrpt851/pdf/GPO-CRPT105hrpt851.pdf,43.

${ }^{38}$ Derek Levine, The Dragon Takes Flight, China's Aviation Policy Achievements and International Implications, Brill: 2015, 137.

39 Phillip, "The Staggering Cost."

$4^{\circ}$ Derek A. Levine, The Dragon Takes Flight, China's Aviation Policy Achievements and International Implications (Boston: Brill, 2015), 2.

${ }^{41}$ Robert D. Atkinson and Caleb Foote, "Is China Catching Up to Us in Innovation?," Information Technology and Innovation Foundation, April 2019, http://www2.itif.org/2019-china-catching-up-innovation.pdf.

${ }^{2}$ News163.com, "China-US Relations Have 'No Turning Back'? Ambassador Liu Xiaoming Responded," accessed August 2, 2020, http://www.yahui.cc/invest/exchange/1987259-1.htm.

43 Sohu.com, "Ren Zeping: Deeper Behind the Sino-US Trade War is the Reform War," Accessed July 12, 2018, https://www.sohu.com/a/240717119_100095661.

44 Henry Gao and Weihuan Zhao, "Are New Rules Needed for China at the WTO?" Global Observatory, April 30, 2019, https://theglobalobservatory.org/2019/04/are-newrules-needed-china-wto/.

45 Yun Li, "Trump Says US Will Impose 10\% Tariffs on Another \$300 billion of Chinese Goods Starting Sept. 1," CNBC, August 8, 2019, https://www.cnbc.com/2019/o8/o1/trump-says-us-will-impose-1opercent-tariffs-on300-billion-of-chinese-goods-starting-september-1.html.

${ }^{46}$ Yun Li, "China Will Retaliate with Tariffs on \$75 Billion More of US Goods and Resume Auto Tariffs," CNBC, August 23, 2019, https://www.cnbc.com/2019/o8/23/china-toretaliate-with-new-tariffs-on-another-75-billion-worth-of-us-goods.html.

47 Corey Bennett and Bryan Bender, "How China Acquires 'The Crown Jewels' of U.S. Technology," Politico, May 22, 2018, https://www.politico.com/story/2018/05/22/china-us-tech-companies-cfius-572413.

$4^{8}$ Gordon Chang (Contributor on China affairs, Fox News), in discussion with the author, November 2019.

49 Marianne Schneider-Petsinger, "The Path Forward on WTO Reform" Chatam House, May 7, 2019, https://www.chathamhouse.org/expert/comment/path-forward-wtoreform.

$5^{\circ}$ Tom Miles, "U.S. Drafts WTO Reform to Halt Handouts for Big and Rich States," Reuters, February 15, 2019, https://www.reuters.com/article/us-usa-trade-wto/usdrafts-wto-reform-to-halt-handouts-for-big-and-rich-states-idUSKCN1Q426T.

${ }^{51} \mathrm{Oh}$, "Convenient Compliance."

$5^{2} \mathrm{Oh}$, "Convenient Compliance."

53 Oh, "Convenient Compliance." 